\title{
METODA I ZNACZENIE \\ W BADANIACH ANKIETOWYCH. \\ PRZYPADEK BADAŃ \\ NAD POSTAWAMI WOBEC ŻYDÓW
}

Antoni Sułek

Uniwersytet Warszawski

„Splacajac dtug naturze, do gwiazd podażyta”

Pamięci Antoniny Kłoskowskiej (1919-2001)

W 1993 r. spytano ogólnokrajowa próbe dorostych, cay zgadzaja sie lub nie zgadzaja z. podanymi im twierdzeniami „o Żydach, którsy syja za granica”. Ze zdaniem,

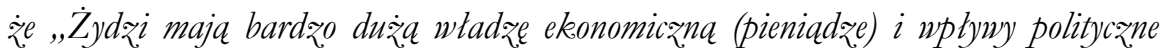
w krajach, w których izyja", zodzito sie 71\% badanych. Latwo to nam uyjaśnić, bo po pierwsze, po drugie, po trzecie... Dobrze to swiadcry o zdolności socjologów do wymyslania wyjaśnien ad hoc, rzeczjednak w tym, ze sondà ten zostat przeprowadzony nie w Polsce, lecz - w państwie Irrael, a jego wynik praytoczyłem po to, by pokazać, jak nieoczywisty $i$ uwarunkowany przez kontekst spoteczeństwa jest sens pytan o wplywy Żydów. Choć w Polsce i w Europie podobne wypowiedzi uznaje sie za antysemickie, to niket przecież nie uzna tych odpowiedzi za dowód istnienia w panstwie żydowskim prawie powszechnego antysemityzmu!

Umiemy układać pytania, zadawać je reprezentatywnym próbom respondentów oraz zliczać i analizować odpowiedzi. Każdej z tych umiejętności i faz badania ankietowego poświęcono wiele artykułów i książek, w tym także podręczników. Umiejętności te zyskały status metody, a metody łatwo można się nauczyć. Gorzej jest z ostatnią i może najważniejszą fazą badania: interpretacją odpowiedzi, określeniem znaczenia uzyskanych wyników, odniesienia ich do pojęć, które konstruują doświadczenie. Nie ma 
na to metod, algorytmów i podręczników. Uczyć tego możemy się na przykładach, egzemplach, casusach. W pracy zostana pokazane, w celach dydaktycznych, problemy określania znaczenia wyników badań ankietowych. Wykorzystane będa prowadzone w Polsce od kilkudziesięciu lat badania nad postawami wobec Żydów, czasem nazywane zawężająco badaniami nad antysemityzmem. Zarówno przedmiot badanych postaw, jak i same te postawy oraz ich badania sa kolejno złożonymi bytami, konstrukcjami i przedsięwzięciami społecznymi, więc na przykładzie tych badań można rozważać wiele zagadnień metodologicznych; są one, mówiąc językiem Roberta Mertona (1987), strategicznym materiałem dydaktycznym.

Praca oparta jest na syntezie badań ankietowych nad postawami wobec Żydów z lat 1967-2008 (Sułek 2011) oraz na badaniach późniejszych, w tym także zaprojektowanych przez autora sondażach TNS OBOP. Przedstawione będą kolejno: problemy z określaniem znaczenia pytań i odpowiedzi numerycznych, pytań o postawy - sympatię i niechęć, bliskość i dystans, odpowiedzi wyrażających przekonania o władzy Żydów oraz problem znaczenia pytań i odpowiedzi w międzykrajowych badaniach porównawczych. Na początku jednak będzie rozważone sondażowe znaczenie słowa „Żydzi” (i ,antysemici”). Tytuł pracy zapożyczony jest z inspirującej książki Howarda Schumana (2008) Method and Meaning in Polls and Surveys.

\section{/// Kto to są „Żydzi”? I „antysemici”?}

W kwestionariuszach ankietowych Żydzi określani byli różnie: „Żydzi”, „Żydzi, którzy żyją w Polsce”, „Żydzi mieszkający w Polsce”, ci „co są Żydami” „osoby pochodzenia żydowskiego”, „obywatele polscy pochodzenia żydowskiego”. Znaczenie słowa „Żydzi” zależy też od odczytania amfibologii, jak w pytaniu o ocenę „wpływu, którzy mają Żydzi w naszym kraju”. W pytaniach ankietowych pojawiają się też "Izraelczycy” - sami, obok „Żydów” lub w niejasnej kombinacji jako „Izraelczycy (Żydzi)”. Zdarza się - zauważył kiedyś Jakub Karpiński - że badani nie wiedzą o kim w pytaniu mowa: ogólnie o Żydach, o Żydach jako narodzie czy o Żydach w Polsce, więc i badacze nie zawsze wiedzą, o kim mówią badani. Nie ma powodu wątpić, że badani odróżniają treściowo kategorie Żydów, Żydów w Polsce i Izraelczyków. O tym, w jakim stopniu wiążą z nimi różne oceny, wiemy jednak bardzo mało.

Barbara Wilska-Duszyńska (1975: 33-40) w przeprowadzonych jeszcze w 1972 r. badaniach postaw studentów polskich wobec różnych narodów pytała o sympatię lub niechęć do „Izraelczyków” i oddzielnie do 
„Żydów”. Izraelczycy i Żydzi zajęli dwa najniższe miejsca w rankingu (za Niemcami), różnica między nimi była, ale niewielka; większa niechęć do Izraelczyków mogła być echem ostrej politycznej krytyki Izraela po wojnie 1967 r. i antyizraelskiego ostrza kampanii ,antysyjonistycznej” po marcu 1968 r. Gdy w 1993 r. CBOS zaczął badać i obserwować zmiany postaw wobec różnych narodów, to zapytał Polaków o stosunek do „Izraelczyków (Żydów)”; w 2002 r. zmienił to określenie na „Żydzi”, nie miało to jednak widocznego wpływu na odpowiedzi (zob. wykres 1, s. 195).

W 1994 i 1999 r. CBOS (1994, 1999) spytał o stosunek do Żydów w Polsce, określonych jako „obywatele polscy pochodzenia żydowskiego”, oraz o stosunek do Żydów jako narodu, takiego jak Francuzi czy Rosjanie. „Żydzi”, choć mniej konkretni, a bardziej abstrakcyjni, wzbudzili żywsze odczucia, byli znacznie rzadziej obojętni niż „obywatele polscy pochodzenia żydowskiego". Pierwsi byli też znacznie częściej niż drudzy przedmiotem niechęci i niechęć do nich przeważała nad sympatią wyraźniej niż niechęć do „obywateli polskich pochodzenia żydowskiego”. W obu przypadkach jednak niechęć deklarowana była ponad dwa razy częściej niż sympatia.

\begin{tabular}{|c|c|c|c|c|}
\hline & \multicolumn{2}{|c|}{$\begin{array}{l}\text { Czy obywatele polscy obcego } \\
\text { pochodzenia wabudzaja u Pana[0] } \\
\text { jakies odcrucia? } \\
\text { zrozl }\end{array}$} & \multicolumn{2}{|c|}{$\begin{array}{l}\text { Jak Pan[i] oireśle[ [o]by swoj] } \\
\text { stcosunek, do innych narodow? } \\
\text { 2rozl }\end{array}$} \\
\hline & 1994 & 1999 & 1994 & 1999 \\
\hline sympatia & 18 & 16 & 17 & 19 \\
\hline obojetnostc & 38 & 45 & 27 & 26 \\
\hline niechęc & 37 & 35 & 47 & 49 \\
\hline trudho powiedziet & 7 & 4 & 9 & 6 \\
\hline
\end{tabular}

Jodelo coos [1994, 1989].

/// Tabela 1. Stosunek do „obywateli polskich żydowskiego pochodzenia” i do „Żydów”. 1994 i 1999 (w \%).

Przywołane sondaże służyły badaniu postaw, a nie efektu pytań. Temu służył dopiero eksperyment typu split-ballot przeprowadzony w $2010 \mathrm{r}$. w TNS OBOP (dane niepublikowane) ${ }^{1}$. W badaniu tym $z$ występującym w polskich sondażach (Krzemiński 1996; Kucia 2011) stwierdzeniem, że

${ }^{1}$ Cytowane w pracy badania OBOP i TNS OBOP zostały zaprojektowane, a wszystkie raporty, oprócz OBOP (1989), zostały napisane przez jej autora. 
„Żydzi w naszym kraju mają zbyt wielki wpływ” zgodziło się $27 \%$ badanych z jednej podpróby, natomiast „wpływ, jaki na sprawy naszego kraju mają Żydzi, którzy żyją w Polsce” uznało za „za duży” 23\% badanych z drugiej podpróby. Różnica w odpowiedziach była, ale niewielka. Być może dlatego, że stwierdzenie: „Żydzi w naszym kraju mają zbyt wielki wpływ” jest amfibolia - jedni badani słowa „w naszym kraju” mogli bowiem łączyć $z$,Żydami”, a drudzy z „wpływem”.

$\mathrm{Na}$ pytanie o stosunek do Żydów i o ocenę ich wpływu uzyskuje się więc nieco wyższe odsetki odpowiedzi zgodnych ze stereotypem antysemickim wtedy, gdy mowa w nim ogólnie o Żydach, niż wtedy, gdy mowa o Żydach w Polsce. Choć myśląc o „Żydach”, badani intensywniej reprodukowali stereotyp, resentyment wobec Żydów okazywał się silny bez względu na to, jakich Żydów mamy na myśli i jak zostali oni nazwani: dla badanych „wszyscy Żydzi są tacy sami”.

Używanie w pytaniach ankietowych rozłącznych kategorii „Żyd” i „Polak” oraz publikowanie wyników badań o stosunku „Polaków do Żydów” budzi uczucie dyskomfortu u wrażliwszych spośród badaczy, którzy tych nazw używaja (Kucia 2011), oraz krytykę ze strony badaczy, którzy ich nie używają (Tokarska-Bakir 2011). Czym jest w sondażach określenie „Żydzi”, jakie ma ono znaczenie i jakich określeń powinno się używać?

Bycie Żydem w Polsce ma wiele odmian i odcieni, ale dokonywane subtelne rozróżnienia (Gebert 1997) nie dają się ują́ w słowa proste i powszechnie zrozumiałe. Standaryzowany sondaż sprawdza się w badaniu takich zjawisk świadomości, które są wykrystalizowane i wyodrębnione językowo, natomiast w świecie płynnych granic i nienazwanych jeszcze tożsamości - a do niego należą tożsamości polsko-żydowskie - bardziej odpowiednie są badania jakościowe, a przynajmniej pytania otwarte, pozwalające na swobodne formułowanie odpowiedzi. Za pomoca reprezentacyjnych sondaży nie bada się jednak tożsamości grup etnicznych, lecz stosunek mieszkańców Polski do ludzi różnych narodów i narodowości, więc słowo „Żydzi” umieszczone w pytaniach nie musi tak bardzo w tym przeszkadzać.

Słowo „Żydzi” jest nazwa pewnej społecznie wytworzonej i odtwarzanej reprezentacji i do tej roli dobrze się nadaje. Żydzi, o których myślą i mówią w sondażach mieszkańcy Polski, to nie tylko ci, którzy żyją w Polsce, ani nawet cały naród żydowski. To Żydzi „symboliczni”, kolektywny byt i zarazem konstrukcja kolektywnej wyobraźni. Dla uprzedzonego umysłu dystynkcje te nie mają jednak większego znaczenia: zakłada on, że ludzie jakiejś kategorii etnicznej zawsze i wszędzie są zasadniczo tacy sami, że w każdym z nich tkwi jakaś wspólna esencja etniczna. 
Język pytań ankietowych powinien być skorelowany z językiem, którym myślą badani, a jego kategorie nie moga być ani zbyt konserwatywne, gdyż raziłyby, ani zbyt awangardowe, gdyż nie byłyby zrozumiałe. Dlatego zresztą studia nad historycznymi zmianami języka pytań ankietowych moga być metoda badania zmian językowych w społeczeństwie, w Ameryce zaś - zmian etykiet etnicznych, od colored w latach 1930., przez Negros, Blacks aż do dzisiejszych African Americans (Smith 1992). Może i w Polsce z czasem zacznie się przyjmować jakiś wymyślony lub nawet już znany etnonim typu Jewish Americans czy African American, Afroamerykanie. Dziś nie przychodzi on nikomu do głowy, ale też dziś nie możemy wiedzieć tego, co wymyślimy lub polubimy jutro. Być może „Żyd-Polak” Piotra Matywieckiego (2010: 5-11) jest określeniem bliskim ideału, ale i ono nie zadowala do końca poety wrażliwego na swą polską i żydowską tożsamość i na język polski. Nawet taka nazwa pozostanie jednak etykietą obejmującą różne polsko-żydowskie tożsamości: Żydów-Polaków, Polaków-Żydów, Żydów polskich, polskich Żydów, Żydów żyjących w Polsce, Polaków pochodzenia żydowskiego, osoby czujące się Polakami i Żydami oraz jeszcze inne.

Wszystko to jednak jest nie tyle sprawą samych słów, ile ich znaczeń, a znaczenie obejmuje też „zabarwienie uczuciowe myśli, na której zasadza się proces rozumienia" (Ajdukiewicz 1965: 23) ${ }^{2}$. Nazwy etniczne nie sa niewinnymi etykietkami, często nie tylko oznaczaja, ale i naznaczają emocjonalnie swoje denotacje, są więc częścią skażonej uprzedzeniami rzeczywistości. Ale i odwrotnie: przypadek amerykański pokazuje, że każda nowa, nieobciążona nazwa $z$ czasem zabarwia się emocjami wobec oznaczanej grupy i staje się neutralna dopiero wtedy, gdy grupa zostanie w pełni zaakceptowana przez społeczeństwo. Nazwa „Żydzi” nie będzie uwierać, jeśli w społeczeństwie zmieni się stosunek uczuciowy do ludzi, do których jest odnoszona. Choć w Polsce „Żyd” nadal bywa epitetem, to równocześnie już około 1989 r. w badaniach nad stereotypami zauważono, że w sprawach gospodarczych „Żyd” i ,żydowski” zmieniaja swoje zabarwienie uczuciowe, znaki: „handlarze” i „kombinatorzy” staja się „uzdolnionymi do handlu”, a „interesowność” - „dbałością o interesy” (Ryszka, Jasińska-Kania 1992). Podejmowane są też próby „odczarowania”

\footnotetext{
2 Tak się złożyło, że Ajdukiewicz zilustrował swą myśl następującym, archaicznym w latach 1960. przykładem: „Są ludzie, dla których wyraz «żyd» łączy się z mającą zabarwienie pogardliwe myślą o ludziach, których przodkowie byli wyznania mojżeszowego, i chcąc tego unikną́, używają wyrazu «izraelita», «starozakonny» itp. Są ludzie, którzy w tym rozumieniu tego wyrazu owego zabarwienia nie znajdują".
} 
słowa „Żyd” - najbardziej znaną były akcje „Tęsknię za Tobą, Żydzie!”, zainicjowane przez performera Rafała Betlejewskiego ${ }^{3}$.

Mniej ważne jest to, co w Polsce będa znaczyć słowa „Żyd” czy „Białorusin”, a ważniejsze jest, jak będzie rozumiana sama „polskość” - po republikańsku, włączająco („wszyscy jesteśmy obywatelami Rzeczpospolitej Polskiej”), czy etnicznie, wykluczająco („Jak Żyd, to nie Polak”). Trzeba, niestety, powiedzieć, że to drugie znaczenie jest zbyt dobrze ukorzenione historycznie i zbyt mocno wspierane w dzisiejszym społeczeństwie, aby można było liczyć na rychły jego uwiąd.

Nie czekając na zmiany w języku, musimy w kwestionariuszach staranniej dobierać i cieniować określenia odnoszące się do grup narodowych.

Pierwszym, wstępnym krokiem mogłoby być sprawdzanie w kontrolowanych porównaniach, do jakich odpowiedzi prowadzą różne określenia użyte w takich samych pytaniach. Trzeba też badać interpretację pytań i znaczenie odpowiedzi badanych, stosując, jak Marek Kucia (2011), zogniskowane wywiady grupowe, ale także wywiady kognitywne lub random probe, losowe sondowanie (Suchman i in. 1996: 15-54), analizę pól semantycznych (Robin 1980) i już podręcznikowy dyferencjał semantyczny ${ }^{4}$. Warto też używać „emicznych” określeń grup etnicznych - takich, których używają w odniesieniu do siebie sami członkowie tych grup. Ciekawe będzie kiedyś sprawdzić, jakie zmiany w wyrażających emocje odpowiedziach mieszkańców Polski spowodowałoby zastąpienie w pytaniach stereotypizującej nazwy „Żydzi” i bardziej realistycznego określenia „Żydzi mieszkający w Polsce” - przyjaznym i inkluzyjnym określeniem „ludzie, którzy sa (czują się) Polakami i Żydami".

Bardziej podstawowy aspekt kwestionariuszowych badań postaw etnicznych dostrzegła w Kulturze narodowej u korzeni Antonina Kłoskowska (1996: 95):

Badania stereotypów i postaw odnoszących się do grup narodowych w szczególności obfituja w sformułowania nie tylko wykrywające istnienie stereotypów w świadomości badanych, ale także skłaniające do formułowania stereotypów i, być może, utwierdzające w stereotypowym myśleniu.

\footnotetext{
${ }^{3}$ Historia zna przypadki takich rewaloryzacji nazw etnicznych. W imperium osmańskim, zanim powstał ruch „młodoturecki”, „termin Turek rzadko był używany i raczej w znaczeniu uwłaczającym, na określenie turkmeńskich nomadów - lub później - ciemnych i nieokrzesanych, mówiących po turecku chłopów z Anatolii. Zastosowanie tego terminu do osmańskiego gentlemana z Konstantynopola byłoby obrazą" (Lewis, 1972: 13-14).

${ }^{4}$ Oto jak zaskakujące bywają wyniki takich badań. Marek Kucia (2011) ustalał w „fokusie” przeprowadzonym z grupą słuchaczy Radia Maryja w Rzeszowie społeczne znaczenie słowa „Żydzi” i usłyszał od jednej z osób badanych rozbrajająca definicję „Żydów” - „ci, co rządzą”; przy takiej definicji zdanie „Żydzi rządzą” jest tautologia.
} 
Reakcje takie może prowokować zarówno żądanie określenia, jacy są w ogóle członkowie danego narodu, jak i polecenie wybrania z listy cech, które uważa się za właściwe dla wymienionej grupy, lub wyrażenia stosunku wobec całej grupy (lubię - lub nie).

Badań postaw wobec Żydów ta wnikliwa uwaga dotyczy w szczególnym stopniu, gdyż Żydzi jako naród postrzegani są esencjalistycznie, jako byt jednorodny, a ich wizerunek społeczny jest bardzo zestandaryzowany, także w skali międzykrajowej. W badaniach nad postawami wobec Żydów łatwo więc potwierdzać istnienie w społeczeństwie ich tradycyjnych stereotypów.

„Żydzi” występują w kwestionariuszach ankietowych w jeszcze jednym, wyjątkowym znaczeniu. Wiemy, że oprócz antysemityzmu politycznego istnieje antysemityzm religijny, antyjudaizm wywodzący się z dawniejszej nauki Kościoła katolickiego (Weil 1987). W sondażach mierzy się go pytaniami o odpowiedzialność Żydów za śmierć Jezusa. W Polsce badani mieli odnosić się do takich stwierdzeń, jak: „Dzisiaj, tak jak dawniej, ciąży na Żydach odpowiedzialność za zabicie Chrystusa" (Golub, Cohen 1995: 45), „Żydzi odpowiadaja za śmierć Chrystusa” (ADL 2009) czy „Żydzi mają tyle kłopotów, ponieważ Bóg ukarał ich za ukrzyżowanie Chrystusa" (Krzemiński 2004); zgodziło się z nimi kolejno 36\%, 48\% i 15\% badanych. Otóż Żydzi z tych pytań (i odpowiedzi) to coś więcej niż dzisiejsza lub nawet współczesna zbiorowość narodowo-religijna rozproszona po świecie. Mowa w nich także o Żydach z czasów ewangelicznych, do tego stopnia tożsamych z Żydami współczesnymi, że Żydzi współcześni mieliby zbiorowo odpowiadać i cierpieć za słowa i czyny Żydów sprzed dwóch tysięcy lat, przy czym teologowie wciąż rozważają, kim są „Żydzi”, oskarżyciele z pozostawionych przez ewangelistów opisów skazania Jezusa - „całym ludem” i „tłumem” czy arystokracją świątynną i ludźmi z tłumu (Ratzinger 2011: 199-202). Żydzi są narodem wyjątkowym, w tym znaczeniu, że na to, jak są dziś odbierani przez ludzi innych narodów, ma wpływ także interpretacja zdarzeń, które wydarzyły się w czasach, w których żaden z tych narodów nie istniał jeszcze na scenie historycznej.

Tak, jak chcemy wiedzieć, kim dla badanych są „Żydzi”, chcielibyśmy też wiedzieć, czym dla badanych jest antysemityzm, jaką treść wiążą oni z tym pojęciem. Można ich o to po prostu zapytać w pytaniu otwartym, jak zrobił to w 1992 r. w swoich referencyjnych badaniach zespół Ireneusza Krzemińskiego (1996: 151-153): „Czy zetknął (zetknęła) się Pan(i) ze słowem «antysemityzm»?", „Jeśli tak, co ono według Pana(i) oznacza?”. "Zetknęło się" z tym słowem dwie trzecie (64\%) badanych, spośród nich $10 \%$ rozumiało je ogólnikowo jako antyżydowskość, 38\% jako niechęć, 
nielubienie Żydów, 21\% jako nienawiść i wrogość, a 16\% jako działanie przeciw Żydom (część odpowiedzi zaliczono do więcej niż jednego typu) ${ }^{5}$.

Takie znaczenie Stefan Nowak nazywal zadeklarowanym i jeszcze w klasycznych badaniach nad „światopoglądem społecznym” studentów Warszawy w 1958 r. wymyślił inną, „korelacyjną metodę kontroli znaczenia odpowiedzi ankietowych", którą zastosowal z powodzeniem do badania znaczenia odpowiedzi autoidentyfikacyjnych (Nowak 1962, 1965: 344-366). Nie pytał badanych, co dla nich znaczy „socjalizm”, lecz o ich stosunek do różnych poglądów uważanych za socjalistyczne czy tylko kojarzonych z socjalizmem, np. akceptację „nacjonalizacji” wielkiego przemysłu, uczynienia rad robotniczych „faktycznymi gospodarzami zakładów pracy” czy „dopuszczenia ograniczenia swobód obywatelskich przez państwo dla realizacji doniosłych społecznie celów”. Następnie sprawdzał, jak różnią się od siebie ci, którzy są za socjalizmem, chcą, by świat „szedł w kierunku jakiejś formy socjalizmu”, od tych, którzy za socjalizmem nie sa. W ten sposób ustalał „empirycznie” znaczenie „konstruowane” bogatego w treść pojęcia ideologicznego. Podobnie Adam Stanowski (1969) badał znaczenie odpowiedzi na pytania autoidentyfikacyjne dotyczące religii.

Przed próbą zastosowania tego podejścia do zbadania społecznego znaczenia tym razem pojęcia antysemityzmu (dla Fryderyka Engelsa „,socjalizmu dla ubogich”) powstrzymuje nas świadomość, że dziś za antysemitów lub sympatyków antysemityzmu najprawdopodobniej nie uznają się lub nie uznaliby się w sondażu nawet ci, którzy osiagają maksymalne wyniki na skalach antysemityzmu budowanych przez jego badaczy. Choć wielu badanych bez skrępowania udziela odpowiedzi zgodnych $z$ antysemickim schematem myślenia, to odraza społeczna do etykiety ,antysemita” jest zbyt wielka, by chcieć jej używać w stosunku do samego siebie. Sam tylko eksperyment myślowy ujawnia więc granice stosowania metody wymyślonej przez autora Studentów Warszany: można jej używać do badania znaczenia tylko takich pojęć, których ludzie używają jako autocharakterystyk.

\footnotetext{
${ }^{5}$ Jako ciekawostkę podaję fakt, że gdy Irena Nowakowska (1991) badała w 1959 r. postawy społeczne pracowników nauki, to w kwestionariuszu ankiety pocztowej umieściła zagadkowe dla nas pytanie: „Czy istnieje zdaniem Pana(i) w Polsce powojennej nacjonalizm?”. Po latach autorka wyjaśniła mi, że „nacjonalizm” był wtedy kryptonimem ,antysemityzmu” (nie wiem, dla kogo i nie wiem, czy zrozumianym przez badanych).
} 


\section{/// Sens pytań i odpowiedzi numerycznych}

W niedawnym sondażu TNS OBOP (2011) badanych poproszono o wymienienie znanych „im narodowości, [które] zamieszkują w Polsce”, przy czym powiedziano im, że chodzi o takich ludzi „wśród obywateli Rzeczpospolitej Polskiej”, „którzy uważają się za Polaków i równocześnie za osoby innych narodowości”. Żydzi okazali się jedną z najbardziej rozpoznawalnych narodowości w Polsce: wyraźnie częściej niż Żydzi (22\%) zostali wymienieni Ukraińcy (42\%), Niemcy (36\%) i Romowie/ Cyganie (32\%), prawie tak samo lub tak samo często Rosjanie $(24 \%)$ i Białorusini (22\%). Stosunkowo często $(10 \%)$ Żydzi byli też spontanicznie zaliczani do narodowości „najliczniejszych”, wyprzedzili ich tylko Ukraińcy, Niemcy i Romowie.

W paru sondażach pytano badanych o to, ilu jest w Polsce Żydów. Badaczami kierowała nie sama ciekawość, lecz przekonanie, że znaczne zawyżanie liczby Żydów jest elementem antysemickiego widzenia świata. Pytanie o liczbę Żydów było zadawane w języku procentów, tysięcy i milionów oraz określeń quasi-ilościowych („dużo”, „mało”). W sondażu CBOS z 1996 r., w odpowiedzi na prekategoryzowane pytanie: „Ilu Żydów mieszka obecnie w naszym kraju?”, 21\% badanych wybrało „dość realistycznie” przedziały do 50 tys., $13 \%$ wybrało „przesadnie” odpowiedź: „do 100 tys.”, pozostałe zaś 32\% odpowiedzi znajdowały się - jak to ujęto w raporcie - „na pograniczu fantazji”": 10\% badanych wybrało: „ćwierć miliona”, 8\%: „pół miliona”, a 14\%: „milion i więcej” (CBOS 1997). W badaniach Krzemińskiego z 2002 r. spytano najpierw: „Czy w Polsce mieszka mało, czy dużo Żydów?”, a potem - „konkretnie, ile”. Odpowiedzi podane są w tabeli 2. Ważnym wynikiem badań jest ustalenie, że wielka część mieszkańców Polski nie zna choćby przybliżonej liczby Żydów w naszym kraju: $26 \%$ badanych samo wybrało odpowiedź: „nie wiem, nie interesowało mnie to", a 15\% - kategorię „trudno powiedzieć”; w badaniach z 1992 r. odpowiedzi takich było jeszcze więcej - łącznie nie 41\%, lecz 50\%, czyli równo połowa (Krzemiński 2004: 95-96). Wiadomo, że w badaniach część respondentów korzysta z oferowanych lub dopuszczonych odpowiedzi typu „nie wiem” i oszczędza sobie wysiłku „,szukania w głowie" materiału na odpowiedzi na trudne pytania, więc zapewne i w tym wypadku w społeczeństwie takich ludzi jest mniej niż w sondażu, ale niewiele mniej ${ }^{6}$.

\footnotetext{
${ }^{6}$ W 1992 r. badani, którzy odpowiedzieli „nie wiem, nie interesowało mnie to” uzyskiwali istotnie statystycznie niższe wskaźniki na skali antysemityzmu (Krzemiński 1996: 256-257). Nie wynika z tego wszakże, że to oni uciekali w kategorie „nie wiem” - liczeniem Żydów pasjonują się raczej antysemici.
} 


\begin{tabular}{|c|c|}
\hline \multicolumn{2}{|c|}{ Czy sqdzi Pan(i], ze w Polsce obecnie mieszka malo czy duto Zyddow? } \\
\hline cuzo + bardzo duzto & $28 \%$ \\
\hline maio + bardzo maio & $51 \%$ \\
\hline rie wiem, nie interesuje mnie to & $14 \%$ \\
\hline trudno powiedziect & 78 \\
\hline \multicolumn{2}{|c|}{ Cry mógtby[aby] Pan[i] powiedziec konkretnie, ilu Żydsw mieszka obecrie w Polsce? } \\
\hline kilkaset tysięcy - kika milionów & $12 \%$ \\
\hline tysiac, dea - kilkadziesiąt tysiçcy & $47 \%$ \\
\hline rie wlem, nie interesuje mnie to & $26 \%$ \\
\hline trudno powiedziect & $15 \%$ \\
\hline
\end{tabular}

/// Tabela 2. Quasi-ilościowe i ilościowe szacunki Żydów w Polsce w 2002 r.

O czym świadczą te liczby, co one znaczą?

1. Przede wszystkim, tak pospolity brak jakiejkolwiek wiedzy o liczbie Żydów w Polsce może świadczyć o tym, że dla znacznej części społeczeństwa nie jest to sprawa istotna - ludzie nie zbieraja i nie magazynuja w pamięci informacji dla nich nieważnych, na tym polega „racjonalna ignorancja" (Page, Shapiro 1992: 14). Skala niewiedzy dotyczącej innych grup etnicznych w Polsce jest zapewne podobna. Ludzie nie maja żadnych szczególnych powodów, by składem etnicznym społeczeństwa interesować się bardziej niż na przykład proporcjami ludzi biednych i bogatych. Przeciwnie, mają tych powodów mniej, gdyż etnicznie społeczeństwo jest prawie jednolite i podziały narodowościowe nie są w Polsce źródłem napięć społecznych. Mówiąc wprost, wiedza o nawet tylko przybliżonej licz̧bie Żydów w Polsce jest ludziom do mało czego potrzebna - do podstawowej orientacji w świecie wystarczy im ogólna wiedza „dużo - mało”.

2. Wiedza ludzi o liczbie Żydów w Polsce nie jest wywiedziona z własnego doświadczenia, lecz jest refleksem wiedzy publicznej. Tak wielu Polaków nie ma żadnego wyobrażenia o liczbie Żydów, ponieważ żadna taka liczba nie funkcjonuje w dyskursie publicznym, więc nie mogli się jej nauczyć. Jeśli natomiast w latach 1992-1994 w Polsce, w Australii, Francji, Niemczech, Wielkiej Brytanii i Stanach Zjednoczonych spośród podanych liczb Żydów zamordowanych w czasie II wojny światowej badani najczęściej (34-36\%) wybierali prawdziwą wielkość 6 milionów (Golub, Cohen 1995: 10-11), to dlatego, że taka liczba jest intensywnie obecna w obiegu publicznym. W wyszukiwarce Google fraza 6 million killed Jews pojawia się ponad $100 \mathrm{mln}$ razy! 
3. Problemem jest jednak nie sam brak wiedzy, ale wiedza fałszywa. Skrajne zawyżanie liczby Żydów może wiązać się, wiąże się (Krzemiński 1996: 256) z postrzeganiem w nich zagrożenia - przekonanie o wszechobecności Żydów faktycznie jest częścią antysemickiego poglądu na świat.

4. Błędne wyobrażenia o rozmiarach mniejszości nie są ani ograniczone do Żydów, ani do grup etnicznych, ani do mniejszości, ani do Polski ${ }^{7}$. Mają one nawet swoją nazwę - demographic lub population innumeracy. W Stanach Zjednoczonych biali Amerykanie dwukrotne przeszacowują odsetek Afroamerykanów, a w Europejskim Sondażu Społecznym (ESS) w 2002 r. mieszkańcy każdego kraju znacząco zawyżyli odsetek imigrantów w całej populacji - Polacy i Włosi najbardziej, bo kilkakrotnie (Herda 2010; Strabac 2011). W Polsce zbadany przez TNS OBOP (2011) średni szacunek liczebności wszystkich narodowości innych niż polska wynosi (w wyrażeniu procentowym) $9 \%$ - jest on mniej więcej trzykrotnie zawyżony i nawet wśród badanych z wyższym wykształceniem wynosi $7 \%$. Okazuje się, że 12,5\% Polaków szacuje, iż spośród 100 obywateli naszego kraju przynajmniej 11 to ludzie innych narodowości - niekiedy są to wyobrażenia podobnie fantastyczne, jak przytoczone wyżej szacunki Żydów ${ }^{8}$.

\begin{tabular}{|c|c|c|}
\hline \multicolumn{3}{|c|}{$\begin{array}{l}\text { llu sposrdd kazdych } 100 \text { obywsteli naszego kraju nalezzy. Pana[i] zdaniem, do wszystkich } \\
\text { narodowosei [infych ni2 polska] razem wziętych? }\end{array}$} \\
\hline & 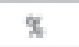 & \% skumulowany \\
\hline do 5 & 29.0 & 29.0 \\
\hline 6 do 10 & 12,7 & 41.7 \\
\hline 11 do 15 & 3.8 & 45,5 \\
\hline 16 do 20 & 4.8 & 50.2 \\
\hline 21 do 50 & 3,9 & 54.1 \\
\hline trudno powiedzied & 45.9 & 1000 \\
\hline
\end{tabular}

Losde ins ceop (2aia)

/// Tabela 3. Zagregowane szacunki łącznej liczebności narodowości innych niż polska w 2011 r.

\footnotetext{
${ }^{7}$ W grudniu 1998 r., w 50 lat po ,zjednoczeniu ruchu robotniczego” i powstaniu Polskiej Zjednoczonej Partii Robotniczej, OBOP (1998) zbadał, jak dużą partią wydawała się ludziom PZPR niedługo po upadku jej rządów, a w konsekwencji i jej samej. Na otwarte pytanie ,ilu dorosłych Polaków na każdych stu" należało do partii pod koniec lat 70., wtedy, gdy PZPR miała najwięcej członków, uzyskano następujące, tu już pogrupowane odpowiedzi: mniej niż $10-4 \%, 10-15-9 \%, 20-5 \%, 30-40-9 \%$; 50\% i więcej - 36\% (!). Faktycznie w 1979 r. do PZPR należało 12,2\% dorosłych Polaków (Sułek 2002). Specyficznych źródeł powszechnego przekonania o tak wysokim upartyjnieniu społeczeństwa w okresie PRL należy szukać w doświadczeniu zbiorowym i w procesach pamięci. Zrośnięta z państwem PZPR była partią wszechobecną i pragnęła - przez swe struktury i „swoich ludzi”, „partyjnych" - kontrolować bez mała wszystko. Partia o tak wielkiej widoczności i tak dużej władzy na zasadzie efektu „halo” mogła utrwalić się w pamięci jako partia wielka także liczebnie.

${ }^{8} \mathrm{~W}$ pytaniu tym nie oferowano badanym żadnych liczb, nawet przedziałów, zgodnie z radą Normana Bradburna: „When you ask about numbers, do not give any numbers” (z wykładów w National Opinion Research Center na Uniwersytecie Chicagowskim w 1993 r.).
} 
Te błędy percepcji społecznej wynikają z kombinacji poczucia zagrożenia i czynników poznawczych, a do drugich należy nasycenie mediów informacjami dotyczącymi mniejszości - im więcej ludzie o nich słysza, tym więcej ich członków „widzą” w swoim społeczeństwie. Niektórym ludziom dlatego może się wydawać, że Żydów w Polsce jest dużo, bo o Żydach, o ich historii, kulturze, stosunkach polsko-żydowskich, mówi i pisze się dużo.

5. Przywołana tu population innumeracy jest tylko odmiana innumeracy, analfabetyzmu liczbowego. Przez analogię do illiteracy, John Paulos (1988) tak nazwał ogólną trudność radzenia sobie z liczbami i pojęciami matematycznymi. Badani zwykle nie znaja żadnych liczb i procentów, więc gdy mają wyrazić swą rozmytą wiedzę w zaproponowanym im języku ilościowym, wybierają wysokie lub niskie liczby bezwzględne i procenty, kierując się swym wyczuciem liczb, a także oferowanymi im skalami (Sułek 2001). Te liczby nie reprezentują więc ich wiedzy ilościowej, lecz tylko quasi-ilościowe wyobrażenia typu „dużo - mało”, przy czym nie znamy ich zasad przekształcania określeń quasi-ilościowych w ilościowe.

6. Wysokie szacunki liczebności Żydów to po części echo historyczne - ludzie przeceniaja wielkość zbiorowości żydowskiej w tych krajach, w których Żydów by to dużo. Także w Austrii (Karmasin 1992: 31), a zapewne i w innych krajach Europy Środkowo-Wschodniej, wciąż duża społeczność żydowska jest fantomem świadomości społecznej, antysemityzm zaś w tym regionie bywa metaforycznie przyrównywany do znanego chirurgom (i ich pacjentom) bólu fantomowego (Wisse 1987; Gross 2006: 30). Fantom ten jest jednak brany za rzeczywistość, a jak nas nauczył W.I. Thomas, ,jeśli ludzie definiują sytuacje jako rzeczywiste, stają się one rzeczywiste w swoich konsekwencjach".

Skoro odpowiedzi zawyżające proporcję Żydów w społeczeństwie mogą wynikać z tylu rozmaitych okoliczności, to nie można tak łatwo uznawać ich za symptom i wskaźnik jednego indicatum, antysemityzmu. Trudno o lepszy dowód słuszności tej przestrogi niż zaskakująco wysoki szacunek liczby Żydów w Polsce, przypisany instytucji żydowsko-polskiej, warszawskiemu Centrum im. Mojżesza Schorra (History 2011). W Polsce ma być około 100 tys. Żydów, z czego tylko 30-40 tys. ,jest w pewien sposób bezpośrednio powiązanych ze społecznością żydowska, religijnie lub kulturowo" - reszta to, powiedziałby Stanisław Ossowski (1967: 159), „członkowie nieuświadomieni albo członkowie potencjalni” żydowskiej grupy narodowej. Te same 100 tys. Żydów w Polsce w oszacowaniu 
instytucji żydowskiej okazuje się być czymś zupełnie innym niż w odpowiedziach na pytanie $z$ reprezentacyjnego sondażu.

\section{/// Postawy - sympatia i niechęć, bliskość i dystans}

Uczucia, zwłaszcza sympatia i niechęć, są najprostszym i najłatwiej uchwytnym składnikiem stosunku do innych i obcych. Pytamy o nie wprost w pytaniach o sympatię i niechęć - lub nieco okrężnie - w pytaniach o różne aspekty dystansu etnicznego.

W 1994 r. CBOS zapytał, w kontekście mniejszości narodowych w Polsce, czy badani byliby przeciw temu, żeby w ich rodzinie ktoś poślubił osobę obcego pochodzenia (CBOS 1994). CBOS zadał też pytanie, czy badani byliby przeciw temu, żeby premierem został Polak pochodzący z którejś z mniejszości. Pierwsze z pytań dotyczy sfery prywatnej, drugie - publicznej.

\begin{tabular}{|c|c|c|c|c|}
\hline & \multicolumn{2}{|c|}{$\begin{array}{l}\text { Cry miat [a]by Pan[0] coś przeciwko } \\
\text { temu, teby w Pana[i] rodzinie ktos } \\
\text { poslubił osobe pochodzania }\end{array}$} & \multicolumn{2}{|c|}{$\begin{array}{l}\text { Cry miat(a)by Pan[i] cos przeciwko } \\
\text { temu, aby premierem zostal } \\
\text { obywatel Polski pochodzenia }\end{array}$} \\
\hline & $\begin{array}{l}\text { By(a)bym } \\
\text { przeciwm(a) }\end{array}$ & $\begin{array}{l}\text { Nie miat }[\text { a }) b y m \text { aic } \\
\text { praciw tamu }\end{array}$ & $\begin{array}{l}\text { Byt[a]bomm } \\
\text { przeciwny(a) }\end{array}$ & $\begin{array}{l}\text { Nee mial(a)bym ric } \\
\text { przacie temu }\end{array}$ \\
\hline siowackjego & 22 & 69 & 48 & 44 \\
\hline creskiego & 23 & 68 & 47 & 45 \\
\hline Etewsikiego & 27 & 66 & 47 & 45 \\
\hline niemieckiego & 27 & 64 & 51 & 42 \\
\hline białoruskiego & 29 & 62 & 46 & 46 \\
\hline rosyjskiego & 32 & 60 & 50 & 42 \\
\hline tydowskiego & 43 & 49 & $\$ 1$ & 42 \\
\hline ukrainskiego & 45 & 47 & $\$ 3$ & 40 \\
\hline cygarskiego & 55 & 38 & S5 & 39 \\
\hline
\end{tabular}

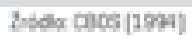

/// Tabela 4. Akceptacja małżeństwa w rodzinie z osobą pochodzącą z mniejszości narodowej oraz akceptacja dla objęcia urzędu premiera przez taką osobę w 1994 r. (w \%).

Polak pochodzenia żydowskiego jako nowy członek rodziny nie byłby akceptowany przez $43 \%$ badanych mieszkańców Polski, akceptowany - przez 49\%. Żydzi byli jedna z wyraźnie najmniej akceptowanych mniejszości (duży skok między nimi a wyprzedzającymi ich Rosjanami), ale też gotowość do akceptacji obcego we własnej rodzinie w stosunku do żadnej z mniejszości nie przekraczała 70\% - Polacy wolą w rodzinie „swoich”. Dystans wobec Żydów zmierzony pytaniem o małżeństwo mieszane zawiera komponent ogólnego dystansu do obcych etnicznie i religijnie, a może 
i szerzej - kulturowo, społecznie. Tendencja do zawierania małżeństw z osobami bliskimi społecznie (homogamia) jest opisana w badaniach nad stratyfikacją społeczną (Domański, Przybysz 2007). Likes marry likes: jednym z głównych kryteriów wyboru małżonka jest w Polsce podobieństwo pozycji społecznej, dlatego np. inteligenci wykazują silną tendencję do zawierania małżeństw z inteligentami, robotnicy z robotnikami, i to samo dotyczy innych warstw. Podstawowym wyjaśnieniem homogamii są ustratyfikowane wcześniejsze kontakty społeczne: zawieramy związki małżeńskie z ludźmi, wśród których żyjemy, ale liczy się także mniejszy koszt wzajemnej adaptacji społecznej i związane z tym mniejsze ryzyko. $Z$ tego punktu widzenia niechęć do akceptacji np. małżeństwa swojego dziecka z kimś wyraźnie odmiennym etnicznie, religijnie czy kulturowo bynajmniej nie musi być powodowana nieufnością do obcych, ale „znajomością życia” i chęcią uniknięcia nadmiernego ryzyka nieudanego związku.

Jeszcze wyraźniej widać, jak niespecyficzny jest dystans wobec Żydów w sferze publicznej. W przywołanym badaniu mniej więcej połowa Polaków nie chciałaby mieć za premiera Polaka pochodzącego z mniejszości narodowej, ale to, czy byłby on Żydem, czy kimś innym, nie ma większego znaczenia. Podobnie w badaniu Krzemińskiego z 2002 r.: 59\% badanych nie głosowałoby na kandydata na prezydenta, gdyby był on osoba pochodzenia żydowskiego, ale równocześnie 63-69\% badanych nie chciałoby mieć za prezydenta Polski osoby pochodzenia niemieckiego, rosyjskiego lub ukraińskiego (Krzemiński 2004: 86-87).

Znaczenie odpowiedzi na pytania o sympatie i dystanse wobec jednej określonej grupy etnicznej możemy więc uchwycić przez wielorakie kontrolowane porównania, gdyż konkretny dystans złożony jest $z$ wielu warstw. Jest to istotne nie tylko wtedy, gdy chcemy ten dystans empirycznie wyodrębnić, ale i wtedy, gdy chcemy go praktycznie wyeliminować. Na antysemityzm składa się szczególna wrogość wobec Żydów i ogólna ksenofobia, dlatego też do wygaszania antysemityzmu potrzebne są, oprócz programów przeciw antysemityzmowi, działania zmniejszające ogólną niechęć do obcych, a nie tylko do Żydów. Badanie długookresowych zmian w społecznych uczuciach wobec Żydów i innych narodów dostarczy dodatkowego potwierdzenia tej prawdy i uzasadnienia tego morału.

Dysponujemy dwiema seriami pomiarów uczuć wobec Żydów: pomiarami OBOP za okres 1975-1991 (OBOP 1989; Jasińska-Kania 1992) oraz pomiarami CBOS od 1993 r. (CBOS 2011). Pytania nie dotyczyły tylko Żydów, ale także wielu innych narodów. Możliwość porównania 
postaw wobec Żydów z postawami wobec innych narodów czyni te badania szczególnie cennymi i pozwala określać znaczenie odpowiedzi na pytania o stosunek do Żydów. Na wykresach pokazano zmiany niechęci wobec Żydów w latach 1993-2010 9. W ciagu prawie dwudziestu lat następuje, choć nie bez regresów, wyraźne ocieplenie stosunku do Żydów - jest ono zresztą kontynuacją wcześniejszego trendu. Tego, co zarejestrowany spadek niechęci do Żydów żnaçyy, nie wiedzielibyśmy jednak bez przedstawienia go na tle zmian w stosunku do innych narodów.

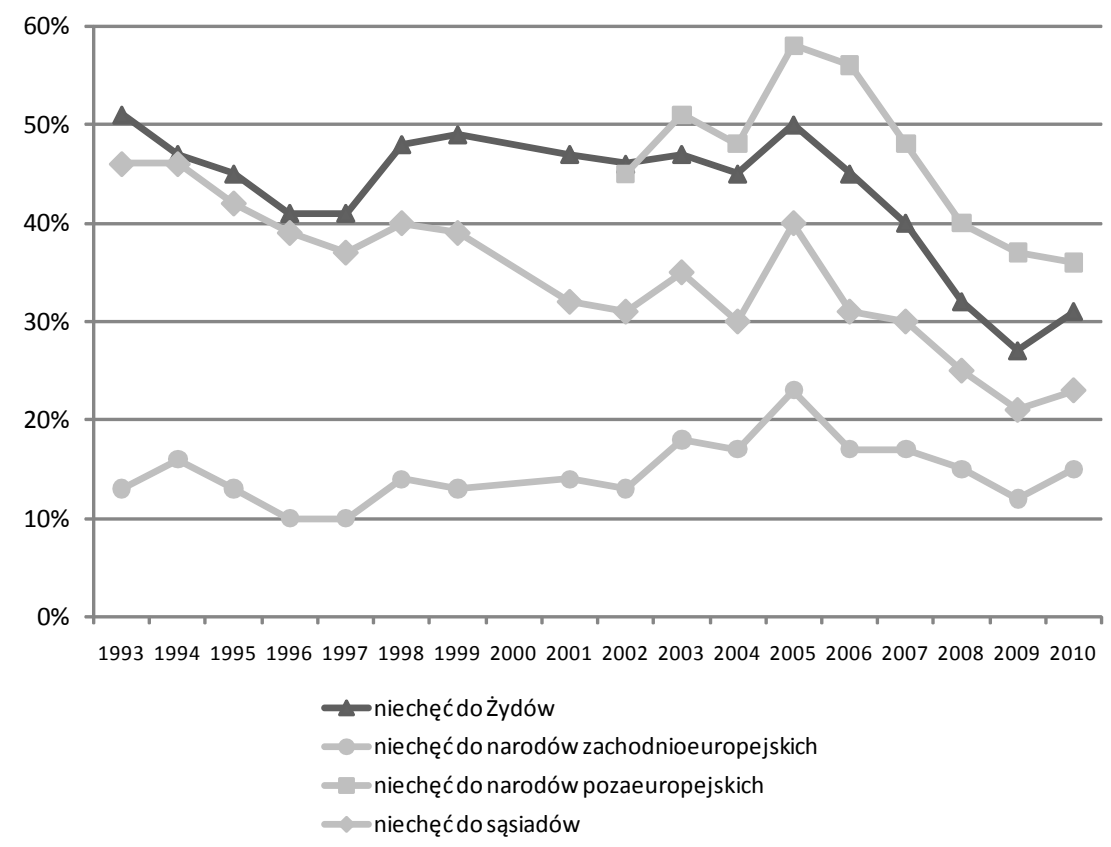

Źródło: na podstawie CBOS (2011)

/// Wykres 1. Niechęć do Żydów na tle niechęci do narodów sąsiedzkich, zachodnioeuropejskich oraz pozaeuropejskich w latach 1993-2010, w \%.

\footnotetext{
${ }^{9}$ Niechęć, a nie sympatia do obcych etnicznie, jest problemem społecznym inspirującym takie badania. Zmiany sympatii do rożnych narodów biegną mniej więcej równolegle także do zmian sympatii do Żydów, a wskaźniki netto (\% sympatii - \% antypatii) są trudniejsze do interpretacji niż ich składowe.
} 


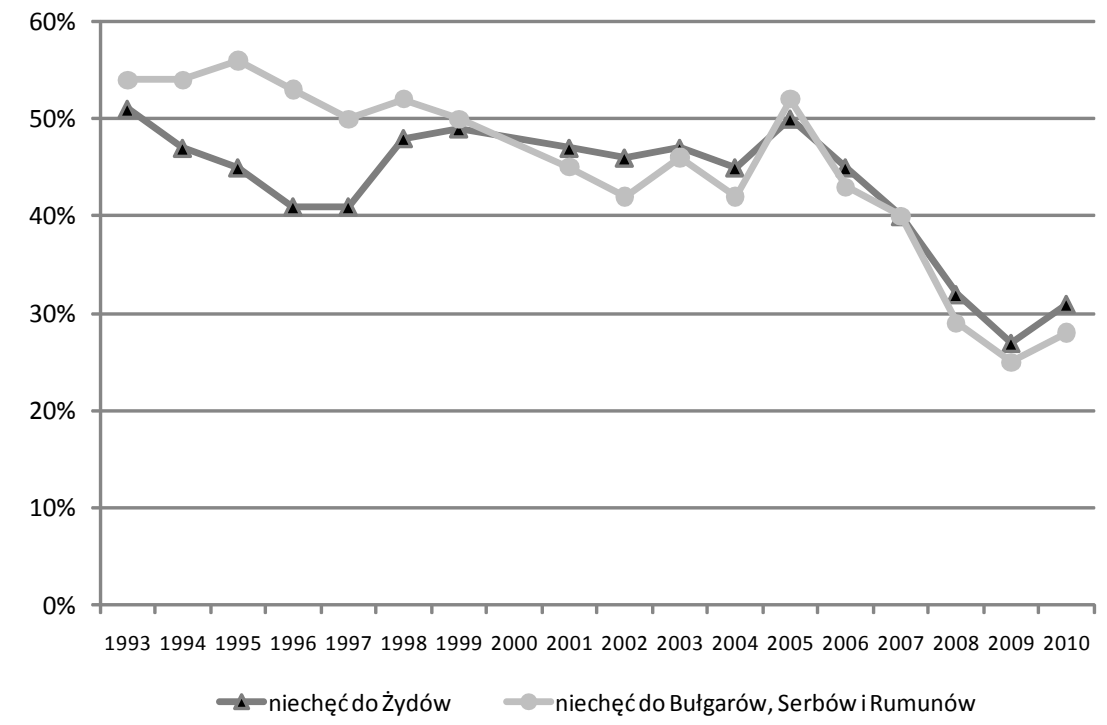

Źródło: na podstawie CBOS (2011)

/// Wykres 2. Niechęć do Żydów na tle niechęci do narodów bałkańskich i Rumunów w latach 1993-2010, w \%.

Okazuje się, że zmiany odsetka niechęci do Żydów postępują mniej więcej równolegle do zmian w odsetku niechęci do wszystkich innych, liczonych łącznie, narodów sąsiedzkich: Niemców, Czechów, Słowaków, Ukraińców, Białorusinów, Litwinów i Rosjan; Żydzi są tu uznani za „sąsiadów wewnętrznych”, na tej samej ziemi. Widać też różnice. W drugiej połowie lat 90 . XX w. niechęci do Żydów przestało ubywać, a nawet przybyło, i aż do połowy następnej dekady utrzymywała się ona na zbliżonym, podwyższonym poziomie. W tym samym czasie erozja niechęci do sąsiadów, choć też zakłócona i przyhamowana, trwała nadal.

Ciekawe jest też porównanie ogólnego spadku niechęci do Żydów ze zmianami niechęci do - jeszcze mniej lubianych niż Żydzi - narodów pozaeuropejskich: Arabów, Chińczyków, Wietnamczyków i (wywodzących się spoza Europy) Romów/Cyganów; niestety CBOS nie bada stosunku do Afrykańczyków. W latach 2002-2011 krzywa niechęci do tych narodów biegła równolegle, lecz na wyraźnie wyższym poziomie niż krzywa niechęci do Żydów. Z krzywą niechęci do Żydów prawie pokrywa się krzywa niechęci do dwóch narodów bałkańskich - Bułgarów i Serbów - oraz Rumunów, dla jasności pokazana na osobnym wykresie. Ta mapa niechęci Polaków do innych narodów może być podstawą do hipotez i analiz dotyczących czynników różnicujących niechęć Polaków do obcych 
(Nowicka 1990; CBOS 2010). Takie próby wyjaśnienia, jakkolwiek pociagające, nie sa jednak celem tego artykułu.

Obserwowany w Polsce spadek niechęci do Żydów jest więc przede wszystkim, choć nie wyłącznie, fragmentem ogólniejszej tendencji do spadku niechęci wobec mniej lubianych narodów. W Polsce maleje ksenofobia i odpływ ten obejmuje wszystkie narody. Prawdopodobnie rzeczywisty spadek jest nieco mniejszy, gdyż badani mogą czuć także rosnąca presję na nieujawnianie niechęci wobec innych narodów, ale nie widać powodów, by wzrost ten dotyczył niechęci tylko wobec Żydów. Dopiero na tym tle można dostrzec miejsce Żydów na skalach uczuć i dystansów wobec narodów. W Polsce są oni lokowani o wiele niżej od narodów zachodnioeuropejskich (łącznie z Amerykanami) i niżej od narodów sąsiednich, mniej więcej na poziomie narodów bałkańskich (z Rumunami), a wyżej od narodów pozaeuropejskich (z Cyganami). Można też dostrzec postępujące zmniejszanie się rozpiętości między uczuciami wobec niektórych spośród tych narodów. Wszystko to dzięki prostym porównaniom.

\section{/// Stereotyp władzy Żydów}

Typem badań, bardziej niż sondaże dystansów etnicznych skupionych na cechach szczególnych stosunku do Żydów, sa badania treści stereotypów i schematów poznawczych. Sama niechęć i cechy negatywne w stereotypie nie wyróżniają stosunku do Żydów spośród postaw wobec innych narodów ${ }^{10}$. Swoiste i kluczowe jest dopiero przekonanie, że Żydzi wywieraja wielki, nieproporcjonalny i niepożądany wpływ na instytucje ekonomiczne, polityczne oraz media, i w ten sposób na całe społeczeństwo - w dodatku niejawnie, skrycie (Datner-Śpiewak 1996; Kofta 2001); naukowo dziś nazywa się to Jewish control (Bilewicz, Krzemiński 2010). Z tym przekonaniem wiąże się niechęć lub nawet nienawiść wobec Żydów. Dlatego w badaniach sondażowych pytanie o ocenę wpływów i władzy Żydów jest najczęściej stosowaną miarą antysemityzmu. Także w Polsce pytanie o wpływy Żydów w różnych mutacjach zadawane jest od początku badań nad stosunkiem do Żydów.

W świetle badań społecznych nie ulega wattpliwości, że znaczna część Polaków łatwo przyjmuje pogląd o dużych, za dużych wpływach Żydów w Polsce. W 2010 r. w sondażach TNS OBOP w zależności od pytania i kontekstu kwestionariusza odsetek takich osób wahał się w szerokich

\footnotetext{
${ }^{10}$ Trudno w tym miejscu o lepszy argument za tą tezą niż negatywne stereotypy Polaków wśród polskich Żydów przed wojną (Hurwic-Nowakowska 1996: 44-45) oraz w niektórych środowiskach Żydów amerykańskich obecnie (Cherry, Orla-Bukowska 2008).
} 
granicach od 22\% (TNS OBOP 2010) do 35\% (Kucia 2011), czyli od jednej piątej do jednej trzeciej populacji. Problemem jest znowu znaczenie, interpretacja tego wyniku. W Polsce ludzi, którzy czują się zarówno Polakami, jak i Żydami („Żydów”) jest niewielu i nie mają oni żadnego specjalngo, kolektywnego i intencjonalnego wpływu na „sprawy naszego kraju”; nie są nawet wyodrębnionym podmiotem w polityce $i \mathrm{w}$ ekonomii. Odpowiedzi na te pytania nie moga więc być traktowane jako po prostu fałszywy opis rzeczywistości, ale jako wyraz akceptacji antysemickiej wiary we „wpływy Żydów”.

Przekonania o wpływie Żydów zawierają także silny element generalnej nieufności do świata, a w Polsce - wiemy to z ESS - „uogólnione zaufanie" należy do najniższych w Europie (Czapiński 2011). Kiedy badani nie oceniają wpływów samych tylko Żydów, lecz wybieraja grupy najbardziej wpływowe spośród im znanych albo też oceniaja po kolei wpływy Żydów i innych grup - a więc muszą myśleć i porównywać Żydów z innymi grupami, a nie tylko odnosić się do przedstawionych im w badaniu klisz i schematów pojęciowych - to przekonanie o wpływie Żydów raptownie traci na popularności. Przekonująco dokumentuje to sondaż CBOS z 2005 r., w którym badani oceniali, ,jak wielkie ukryte wpływy ma dana grupa lub organizacja". Żydzi okazali się jedna z najmniej, a nie najbardziej wpływowych grup ukrytej władzy „w Polsce, w Europie i na świecie”.

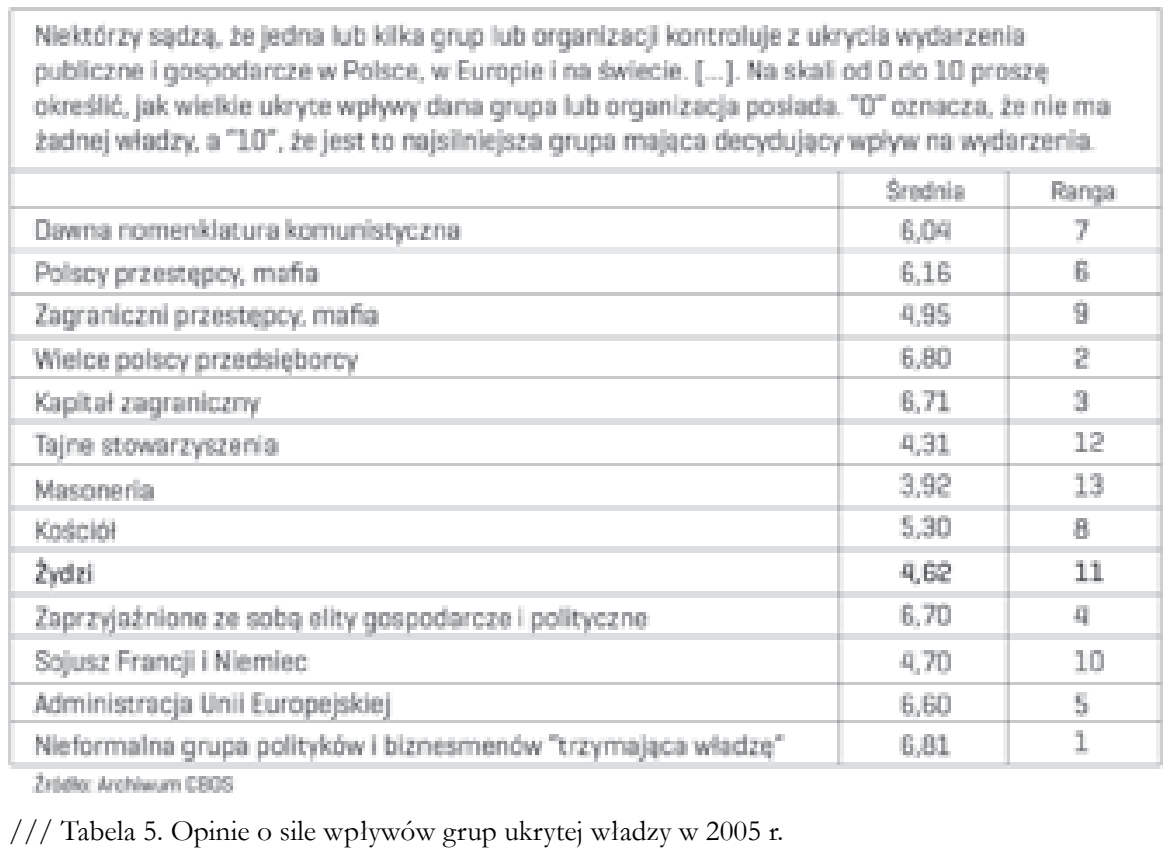


Co jednak znaczą te odpowiedzi w stosunku do przekonań dotyczących samych Żydów? Jaka jest struktura tych przekonań?

Tradycyjny pogląd na naturę ludzkich opinii jest mniej więcej taki: ludzie opinie maja, tak jak maja nazwiska, dzieci czy adresy. Maja je już przed badaniem i są one względnie stałe. W sondażu ludzie te opinie tylko ujawniaja, badanie zaś trafnie lub mniej trafnie je rejestruje. Zapytani przez ankietera, otwierają stosowną szufladkę w swojej głowie i odczytują gotową opinię. Tak faktycznie często jest, ale jest to tylko jeden z krańców continuum sytuacji spotykanych w badaniu opinii. $\mathrm{O}$ wielu badanych sprawach ankietowani wcześniej nie myśleli, a jeśli myśleli, to nie na tyle, by w ich umysłach uformował się trwały pogląd, który wystarczy przywołać i wypowiedzieć przed ankieterem. W takich sprawach ludzie maja raczej inklinacje, dyspozycje, tendencje, ich odpowiedź zaś powstaje na miejscu, na poczekaniu, na gorąco - w sytuacji badania; powstaje z połączenia głębszych inklinacji z informacjami najłatwiej dostępnymi, np. z ostatnio nagłośnionymi przez media (Zaller 1992; Tourangeau, Rips, Rasinski 2000). Pytania o „wpływy Żydów” należą do tych, na które część badanych ma gotowe odpowiedzi, gdyż ma poglądy, ale część dopiero próbuje je stworzyć, nie zawsze (co widać z dużych odsetków odpowiedzi beztreściowych, typu: „nie wiem”) z powodzeniem.

Przytoczone wyżej wyniki badania TNS OBOP nie daja podstawy do prostego wniosku, że znaczna część Polaków „uważa”, iż Żydzi maja w Polsce za duże wpływy (a sondaż tylko to ujawnił). Skłonność do akceptacji takiego stwierdzenia $\mathrm{w}$ testowej sytuacji badania świadczy natomiast o tym, że schemat „wpływu Żydów” jest w Polsce głęboko zakorzeniony w świadomości zbiorowej, ale zarazem łatwo dostępny poznawczo.

Różnicę między tymi dwoma wnioskami rozjaśnia eksperyment sondażowy przeprowadzony przez autora w TNS OBOP w $2002 \mathrm{r}$. i powtórzony w 2010 r. (TNS OBOP, 2010; Sułek, w druku). W sondażach tych badanych poproszono najpierw, by sami wymienili ,grupy, które maja za duży wpływ na sprawy naszego kraju"; w 2010 r. 33\% wymieniło polityków, 14\% - Kościół i księży, a 13\% - biznesmenów i bogatych; Żydów spontanicznie wymieniło $2 \%$, a dokładnie $1,9 \%$ badanych. Dopiero potem badanych zapytano, „czy któraś z mniejszości narodowych żyjących Polsce ma za duży wpływ na sprawy naszego kraju" - teraz Żydów wymieniło spontanicznie 6\%. Na koniec spytano wprost: „Jaki wpływ na sprawy naszego kraju mają Żydzi, którzy żyja w Polsce?” - w 2010 r. 22\% badanych wybrało odpowiedź „za duży”. 


\begin{tabular}{|c|c|c|}
\hline Ddmiana pytania & 2002 & 2010 \\
\hline $\begin{array}{l}\text { Jakie grupy, jacy ludzie w nastym spoieczenstwie maja za duty } \\
\text { woływ na sprawy naszego kraju? } \\
\text { Spontanicznic: } 2 \text { Yozl }\end{array}$ & $1 \%$ & $2 \%$ \\
\hline $\begin{array}{l}\text { Czy któras z mniejszosci narodowych tyjacych w Polsce ma za duzy } \\
\text { lub za maly wplyw na sprawy naszego kraju? } \\
\text { Spontanicznie: ZYozl }\end{array}$ & $19 \%$ & $6 \%$ \\
\hline $\begin{array}{l}\text { A jaki wphw na sprawy naszego kraju maja Zzydzi, którzy ży/a } \\
\text { w Polsce - za dužy, za maty, czy taki, jak powinni? } \\
\text { ZA DUžY }\end{array}$ & $43 \%$ & $22 \%$ \\
\hline
\end{tabular}

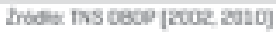

/// Tabela 6. Postrzegane wpływy Żydów przy trzech odmianach pytania, w latach 2002-2010.

Co znaczą te odpowiedzi na kolejne pytania? Nie tylko, że odpowiedź zależy od pytania - od jego sformułowania, użytych w nim słów, jego formy i kontekstu. To byłoby banalne. Zależy dlatego, że pytania mają inne znaczenie, dotyczą innych warstw świadomości. Przekonanie o władzy Żydów ma strukturę wielowarstwowa. Poszczególne warstwy ujawniaja się w różnych sytuacjach badawczych, określonych przez typ pytań jedne pytania docierają do głębszych inklinacji, a inne służą do rejestracji przekonań znajdujących się na powierzchni. Odpowiedzi na różne pytania co innego znaczq.

Wyniki tego badania przemawiaja na rzecz trzech tez.

1. Wpływ Żydów nie jest w Polsce kwestią obecną w potocznym myśleniu i na tyle wyrazista, by była ona wywoływana z umysłu niemal automatycznie, ilekroć ludzie zaczną myśleć o rządach w kraju. W codziennych rozmowach o polityce, o grupach uprzywilejowanych i upośledzonych w dostępie do władzy kategorie etniczne pojawiaja się rzadko i nie ma (w badaniach) dowodu na to, iż Polacy myślą, że „wszystko to przez Żydów" - a nie na przykład przez polityków czy biznesmenów, obcy kapitał i aferzystów.

2. W Polsce schemat „wpływu Żydów” łatwo jest aktywizować. Drogę do niego mogą torować nawet słabe bodźce, np. samo przywołanie kontekstu etnicznego („mniejszość narodowa”), nie mówiąc już o bezpośrednim poruszeniu tematu władzy Żydów. Ludzie, którym raczej wyjątkowo przychodzi do głowy myśl, że Żydzi maja w Polsce za duże wpływy, dosyć łatwo zgadzają się z tym stwierdzeniem, gdy już się z nim zetkna.

3. Dziś samo wspomnienie nieokreślonych mniejszości narodowych i ich wpływów znacznie trudniej toruje drogę do schematu władzy Żydów 
niż jeszcze kilka lat temu. W 2002 r. 19\% badanych do aktywizowania schematu potrzebowało tylko wspomnienia o mniejszościach narodowych. Dziś natomiast zbliżony odsetek badanych (22\%) do uzyskania tego efektu potrzebuje znacznie silniejszego bodźca - przywołania explicite stereotypu wpływu Żydów. Eksperymentalne badanie znaczenia pytań i odpowiedzi ankietowych pozwala więc także uchwycić trudno dostrzegalne wymiary zmiany przekonań społecznych.

\section{/// Znaczenie pytań w badaniach porównawczych}

Badania postaw wobec Żydów prowadzone są w wielu krajach, antysemityzm jest bowiem problemem transnarodowym. Proste porównania typu nation-oriented dają odpowiedź na pytanie, jak dany kraj wygląda na tle innych. Opisowe sondaże, z gatunku badań American Jewish Committee (AJC), służą monitorowaniu stanu i zmian natężenia postaw antysemickich $\mathrm{w}$ różnych krajach. Bardziej wyrafinowane badania, typu variable-oriented, nie służa porównaniom, porównania służą natomiast wyjaśnianiu różnic między krajami, np. różnic w natężeniu antysemityzmu (Przeworski, Teune 1970; Nowak 1977). Badania porównawcze każdego typu wymagaja porównywalności miar i nie chodzi tu o identyczność pytań, ale o ich ekwiwalencję, o to samo znaczenie teoretyczne, albowiem w różnych społeczeństwach to samo znaczenie moga mieć dopiero różne pytania. Charles Osgood (1967), sławny badacz znaczeń, już dawno ujął ten złożony problem w formie czterech prostych pytań:

\section{When is the same really the same? \\ When is the same really different? \\ When is different really the same? \\ When is different really different?}

Badania nad postawami wobec Żydów dostarczają dobrej ilustracji tego problemu. W takich badaniach pyta się ludzi w różnych krajach, czy w ich opinii Żydzi mają dużo, czy też za dużo władzy.

Jeśli pyta się o wpływy Żydów na sprawy świata, to odpowiedź twierdząca w każdym z krajów znaczy to samo - wiara w to, że „Żydzi rządzą światem", należy do tradycji i kanonu myślenia antysemickiego. Przykładowo, w wielonarodowym sondażu AJC w 2005 r. 56\% badanych w Polsce, 45\% w Austrii, 36\% w Niemczech i 27-31\% w Szwecji, Wielkiej Brytanii, Stanach Zjednoczonych i Francji zgodziło się ze stwierdzeniem: „Teraz, tak jak w przeszłości, Żydzi maja zbyt duży wpływ na to, co się dzieje w świecie" (AJC 2005). Na tej podstawie możemy 
wypowiadać się o międzykrajowych różnicach w rozpowszechnieniu antysemityzmu politycznego.

Jeśli jednak pytanie nie dotyczy „Żydów”i „świata”, ale wpływów Żydów żyjących w różnych krajach na sprawy tych krajów, rzecz się komplikuje. W opinii Fredericka Weila (1987: 174-175), ,pytanie o władzę Żydów nie jest czystą miarą antysemityzmu, ponieważ zawiera składnik szacujący lub empiryczny - czy Żydzi mają proporcjonalnie więcej władzy niż wynosi ich udział w populacji”. W odniesieniu do społeczeństwa amerykańskiego Tom Smith (1994: 5-6), dyrektor General Social Survey, stwierdził, że wprawdzie w utrzymywaniu się opinii o nadmiernych wpływach Żydów można widzieć świadectwo trwałości antysemickiego stereotypu, ale zarazem „wiele z tych opinii nie wyraża wrogości wobec Żydów ani wezwania do działania w celu zaradzenia tej sytuacji”. Na przykład, ci Amerykanie, którzy mówią, że Żydzi maja za dużo władzy w biznesie, rzadko uważają, że „trzeba coś zrobić, żeby odebrać Żydom władzę”, a jeśli już, to zwykle nie dlatego, że żywią antyżydowski resentyment, ale dlatego, iż są zdania, że trzeba ograniczyć monopole, wielkość przedsiębiorstw itd.

Tak jest w Ameryce i jest to jeszcze jeden argument za tym, że w porównaniach międzykrajowych „to samo nie znaczy to samo” i że wartość pytania o władzę Żydów jako miary antysemityzmu politycznego nie we wszystkich krajach jest taka sama - jest tym większa, im mniejsza, mniej wyodrębniona, mniej zorganizowana i mniej znacząca w tym kraju jest zbiorowość żydowska. Dlatego np. odpowiedzi 29\% Amerykanów, którzy w sondażu Harrisa w 1986 r. zgodzili się ze stwierdzeniem: „The Jewish lobby in the United States is far too powerful for the good of this country" (Smith 1994: 43) nie maja takiego samego znaczenia, jak odpowiedzi 22\% Polaków, którzy w 2010 r. w sondażu TNS OBOP wybrali odpowiedź: „za duży” na pytanie: „Jaki wpływ na sprawy naszego kraju maja Żydzi, którzy mieszkają w Polsce?” (TNS OBOP 2010). W Polsce to pytanie jest „czystą miarą" antysemityzmu, a w Ameryce ta miara jest kontaminowana, zanieczyszczona przez oszacowanie znaczenia zorganizowanych Jewish Americans w życiu Stanów Zjednoczonych.

W szkicu zatytułowanym How comparative is comparative research? Roger Jowell (1998) przestrzegał przed łatwym uznawaniem różnic w wynikach porównań międzykrajowych za dowód istnienia faktycznych różnic między krajami. W szczególności zwracał uwage, że drobne różnice w uzyskanych danych wynikają prawdopodobnie albo z różnic $\mathrm{w}$ brzmieniu pytań i ich rozumieniu przez badanych, albo z różnic w przebiegu badań i społecznych warunkach ich realizacji, w tym w sile presji na udzielanie 
odpowiedzi społecznie pożądanych i unikanie niepożądanych. Nie warto więc próbować wyjaśniać socjologicznie paroprocentowych różnic w natężeniu antysemityzmu - skoro one moga tyle znaczyć, to znaczy, że nic nie znacza. Znaczenie i przyczyny mają natomiast wyraźne różnice między grupami krajów. Większe natężenie antysemityzmu w krajach Europy ŚrodkowoWschodniej w porównaniu z centrum Europy Zachodniej Frederick Weil (1985) wyjaśniał historia tych krajów: wielowiekową obecnością Żydów, antysemickimi nacjonalizmami, dominacją katolicyzmu i brakiem tradycji liberalnej demokracji w Europie Środkowej. Werner Bergmann (2008) natomiast tłumaczy zróżnicowanie antysemityzmu w Europie stosunkiem społeczeństw do historii swych krajów: w krajach, które dokonały i wspomagały zagładę Żydów lub były generalnie obojętne na ich los i nie przepracowały jeszcze tego doświadczenia, Żydzi postrzegani są często jako zagrożenie dla tożsamości narodowej i samooceny moralnej społeczeństw.

Dyrektor ESS przestrzegał też przed nadmiernym rozszerzaniem skali porównań międzykrajowych, wykraczającym poza granice naszej wiedzy kontekstowej o badanych krajach. „Badacze społeczni nie powinni podejmować interpretacji danych dotyczących krajów, o których wiedzą bardzo mało albo nic" - brzmi pierwsza z jego dziesięciu very practical rules of thumb. I dalej: „W istocie rzeczy analityk, któremu brakuje szczegółowej wiedzy o strukturze społecznej, historii i kulturze kraju lub krajów, nie może zrobić wiele więcej niż opisywać i gapić się na zróżnicowania”.

To samo pozostaje badaczowi, który nie wie, jakie znaczenia przypisuje się w różnych społeczeństwach jednakowo lub podobnie brzmiącym pytaniom i odpowiedziom. Dlatego bez znajomości społeczeństwa izraelskiego możemy tylko „gapić się" na te $71 \%$ żydowskich mieszkańców Izraela, którzy w sondażu z 1993 r. zgodzili się ze stwierdzeniem, że Żydzi (wraz z Izraelczykami), którzy mieszkają za granica, ,mają bardzo dużą siłę ekonomiczną (pieniądze) i wpływ polityczny w krajach, w których żyja” "11, podczas gdy w 2008 r. w Polsce na pytanie: „Jaki wpływ na sprawy naszego kraju mają Żydzi, którzy żyją w Polsce?” („duży” czy „mały”)

\footnotetext{
${ }^{11} \mathrm{~W}$ thum. ang:: ,Jews have a lot of economic power (money) and political influence in the countries where they live"; $28 \%$ badanych nie zgodziło się z tym twierdzeniem, a $1 \%$ odmówił odpowiedzi; Israel Democracy Institute, Guttman Center, Continuing Survey, week 266, 1064 (February 14thMarch 22nd, 1993); dane uzyskane z IDI. Dr Raphael Ventura z Centrum Guttmana wyjaśnił mi, że „most Israeli Jews understand this statement as referring to positive attributes of Jews, showing how important and prominent Jews are all over the world" (e-mail z 13 lipca 2011). Patron Centrum to ten Guttman od Żotnierza amerykańskiego i „skalogramu Guttmana”. Louis Guttman (1916-1987) po wojnie, w 1947 r., wyjechał do Palestyny i założył, tym razem w podziemnym wojsku żydowskim, jednostkę badawcza, zalążek późniejszego Izraelskiego Instytutu Stosowanych Badań Społecznych.
} 
badani odpowiedzieli „odwrotnie”: 26\% odpowiedziało, że „duży”, a 54\% - że „mały” (TNS OBOP 2008) ${ }^{12}$.

\section{/// Konkluzja}

Stereotypowo znaczenie to coś dostępnego przez wyobraźnię, empatię i sympatię, a metoda to dyscyplina, rygor, algorytm. Produkty metody słowa, liczby i teksty - domagaja sie jednak interpretacji ${ }^{13}$. W tym wykładzie z metodologii pokazałem, że i jak za pomocą zdyscyplinowanego myślenia i podstawowych narzędzi z warsztatu socjologii możemy ustalać znaczenie uzyskanych odpowiedzi i dobierać metody tak, by dawały odpowiedzi, które będą znaczyć to, co miały znaczyć. Metoda sondażowa może być użyta do rozjaśniania znaczenia swoich własnych wytworów.

Anonimowemu recenzentowi „Stanu Rzeçy” bardzo dziekuje za wnikliwe komentarze do maszynopisu tego artykutu.

Bibliografia:

/// ADL. 2009. Attitudes toward Jews in Seven European Countries, raport z badania. URL=www.adl.org; dostęp: 20.06.2011.

/// AJC. 2005. Thinking about the Holocaust 60 Years Later. A Multinational Public-Opinion Survey, raport z badania. URL=www.ajc.org; dostęp: 20.06.2011.

/// Ajdukiewicz, Kazimierz. 1965. Logika pragmatyczna. Warszawa: Państwowe Wydawnictwo Naukowe.

/// Bergmann, Werner. 2008. Anti-Semitic attitudes in Europe: a comparative perspective. „Journal of Social Issues” 64, 2, s. 343-362.

/// Bilewicz, Michał, Krzemiński, Ireneusz. 2010. Anti-Semitism in Poland and Ukraine: The belief in Jewish control as a mechanism of scapegoating. „International Journal of Conflict and Violence" 4, 2, s. 234-243.

/// Cherry, Robert, Orla-Bukowska, Annamaria (red.). 2008. Polacy i Żydži - kwestia otwarta. Warszawa: Więź.

\footnotetext{
${ }^{12}$ Jest kilka polskich badań pochodzących z tego samego okresu, co sondaż izraelski, ale w badaniach tych pytano o wpływ „Żydów”, a nie „Żydów, którzy żyją w Polsce”, oraz o to, czy wpływ ten jest za duży, czy za mały, a nie, czy jest on duży, czy mały.

${ }^{13}$ Pewien średniowieczny filozof żydowski napisał, że tekst krzyczy: „odczytaj mnie, zinterpretuj mnie!”; z wystawy „Taswir - Islamische Bildwelten und Moderne”, Berlin, Martin-Gropius-Bau, grudzień 2009.
} 
/// CBOS. 1994. Stosunek Polakón do przedstawicieli mniejszości narodonych mieszkejacych w Polsce, komunikat z badania.

/// CBOS. 1997. Żydzi i Polacy w opiniach spoteczeństwa, komunikat z badania. /// CBOS. 1999. Stosunek do mniejszości narodowych, komunikat z badania.

/// CBOS. 2011. Stosunek Polakón do innych narodów, komunikat z badania.

/// Czapiński, Janusz. 2011. Kapitał społeczny. W: Janusz Czapiński, Tomasz Panek (red.). Diagnoza Społeczna 2011. Warunki i jakość sycia Polaków. Warszawa: Rada Monitoringu Społecznego, s. 285-293.

/// Datner-Śpiewak, Helena. 1996. Struktura inyznacznikipostaw antysemickich. W: Ireneusz Krzemiński (red.). C3y Polacy sq antysemitami? Wyniki badania ankietowego. Warszawa: Oficyna Naukowa, s. 27-64.

/// Domański, Henryk, Przybysz, Dariusz. 2007. Homogamia maťreńska a bierarchie spoteczne. Warszawa: Wydawnictwo IFiS PAN.

/// Gebert, Konstanty. 1997. Tȯ̇samości Żydów w Polsce: „nowa”, „dawna” $i$,ayysnuta z. ayobražni”. „Polis” 3, s. 45-49.

/// Golub, Jennifer, Cohen, Renae. 1995. Knowledge and Remembrance of the Holocaust in Poland. New York: American Jewish Committee.

/// Gross, Jan T. 2006. Fear. Anti-Semitism in Poland after Auschwitz: An Essay in Historical Interpretation. New York: Random House.

/// Herda, Daniel. 2010. How many immigrants? Foreign-born population innumeracy in Europe. „Public Opinion Quarterly” 74, 4, s. 674-695.

/// History of the Jews in Poland. 2011. http://en.wikipedia.org/wiki/History_of_the_Jews_in_Poland 2; dostęp: 06.2011.

/// Hurwic-Nowakowska, Irena. 1996. Żydzi polscy (1947-1950). Analiza wiezi spotecznej ludności isydowskiej. Warszawa: Wydawnictwo IFiS PAN.

/// Jasińska-Kania, Aleksandra. 1992. Zmiany stosunku Polakón do różnych narodów $i$ państw. W: Bliscy $i$ dalecy. Warszawa: Instytut Socjologii UW, s. 219-246.

/// Jowell, Roger. 1998. How comparative is comparative research? „American Behavioral Scientist" 42, 2, s. 168-177.

/// Karmasin, Fritz. 1992. Austrian Attitudes toward Jews, Israel, and the Holocaust. New York: American Jewish Committee.

/// Kłoskowska, Antonina. 1996. Kultury narodowe u korzeni. Warszawa: Wydawnictwo Naukowe PWN.

/// Kofta, Mirosław. 2001. Stereotyp spiskowy jako centralny składnik antysemityzmu. W: Mirosław Kofta, Aleksandra Jasińska-Kania (red.). Stereotypy $i$ uprzedzenia. Uwarunkowania psychologiczne $i$ kulturowe. Warszawa: Wydawnictwo Naukowe Scholar, s. 274-296. 
/// Krzemiński, Ireneusz (red.). 1996. C:y Polacy sq antysemitami? Wyniki badania ankietowego. Warszawa: Oficyna Naukowa.

/// Krzemiński, Ireneusz. 2004. O Żydach $i$ antysemityrmie po 10 latach. W: Ireneusz Krzemiński (red.). Antysemityzm w Polsce i na Ukrainie. Raport z.badań. Warszawa: Wydawnictwo Naukowe Scholar, s. 13-168.

/// Kucia, Marek (red) 2011. Antysemityzm, Holokaust, Auschwitz, w badaniach społecznych. Kraków: Wydawnictwo Uniwersytetu Jagiellońskiego.

/// Lewis, Bernard. 1972. Narodziny nowoczesnej Turcji. Tłum. Kazimierz Dorosz. Warszawa: Państwowe Wydawnictwo Naukowe.

/// Matywiecki, Piotr. 2010. Dwa oddechy. Szkice o tożsamości żydowskiej i chrześsijańskiej. Warszawa: Więź.

/// Merton, Robert K. 1987. Three fragments from a sociologist's notebooks: establishing the phenomenon, specified ignorance, and strategic research materials. „Annual Review of Sociology” 13, s. 1-28.

/// Nowak, Stefan. 1962. Correlational approach to the control of meaning of attitudinal variables in cross-cultural surveys. „Polish Sociological Bulletin” 3-4, s. 15-27.

/// Nowak, Stefan. 1965. Studia z metodologii nauk spotecznych. Warszawa: Państwowe Wydawnictwo Naukowe.

/// Nowak, Stefan. 1977. The strategy of cross-national research for the development of social Theory. W: A. Szalai, R. Petrella (ed.). Cross-national Comparative Survey Research: Theory and Practice. Oxford: Pergamon, s. 3-47.

/// Nowakowska, Irena. 1991. Postany społeczne pracowników nauki. „Zagadnienia Naukoznawstwa" 3-4, s. 387-412.

/// Nowicka, Ewa (red.). 1990. Swoi i obcy. Warszawa: Instytut Socjologii UW.

/// OBOP. 1989. Stosunek do Niemców i Żydów w badaniach OBOP, 1989, komunikat z badania.

/// OBOP. 1998. Pamiéć po PZPR. W piéćdziesiata rocznice ponstania Polskiej Zjednoczonej Partii Robotniczej, komunikat z badania.

/// Osgood, Charles E. 1967. On the strategy of cross-national research into subjective culture. „Social Science Information” 6, 1, s. 5-37.

/// Ossowski, Stanisław. 1967. O osobliwościach nauk społecznych (1962). W: S. Ossowski. Dzieła. T. 4: O nauce. Warszawa: Państwowe Wydawnictwo Naukowe.

/// Page, Benjamin I., Shapiro, Robert Y. 1992. The Rational Public. Fifty Years of Trends in Americans' Policy Preferences. Chicago: University of Chicago Press. 
/// Paulos, John A. 1988. Innumeracy. Mathematical Illiteracy and its Consequences. New York: Hill and Wang.

/// Przeworski, Adam, Teune, Henry. 1970. The Logic of Comparative Social Inquiry. New York: Wiley.

/// Ratzinger, Joseph (Benedykt XIV). 2011. Jezus z Nazaretu. Cz. 2. Od wjazdu do Jerozolimy do Zmartwychwstania. Tłum. Wiesław Szymona. Kielce: Jedność.

/// Robin, Regine. 1980. Badanie pól semantycznych: doświadczenia Ośrodka Leksykologii Politycznej w Saint-Cloud. W: Michał Głowiński (red.). Jeaylke i społeczeństwo. Warszawa: Czytelnik, s. 252-281.

/// Rogers, Andrei.1995. Combatting demographic innumeracy with social accounting principles: heterogeneity, selection, and the dynamics of interdependent populations. W: G.eoffrey J. D. Hewings i Moss Madden (ed.). Social and Demographic Accountings, Cambridge: Cambridge University Press, s. 180-194.

/// Ryszka, Franciszek, Jasińska-Kania, Aleksandra. 1992. Antysemityzm polski. Szkic do opisu i diagnozy. W: Bliscy i dalecy. Warszawa: Instytut Socjologii UW. s. 167-199.

/// Schuman, Howard. 2008. Method and Meaning in Polls and Surveys. Cambridge, MA: Harvard University Press.

/// Smith, Tom W. 1992. Changing racial labels: from 'colored' to 'Negro' to 'blacks' to 'African American'. „Public Opinion Quarterly” 56, 4, s. 496-514.

/// Smith, Tom W. 1994. Anti-Semitism in Contemporary America. New York: American Jewish Committee.

/// Stanowski, Adam. 1969. Odpowiedzi autoidentyfikacyjne jako wskaźniki postaw wobec religii. Niepublikowana praca doktorska. Biblioteka Wydziału Filozofii i Socjologii UW.

/// Strabac, Zan. 2011. It is the eyes and not the size that matters. The real and perceived size of immigrant populations and anti-immigrant prejudice in Western Europe. „European Societies” 13, 3, s. 559-582.

/// Suchman, Stanley, Bradburn, Norman M., Schwarz, Norbert. 1996. Thinking about Answers. The Application of Cognitive Processes to Survey Methodology. San Francisco: Jossey-Bass.

/// Sułek, Antoni. 2001. „Ilu Żydów jest w Polsce?” Eksperymentalne studium wplywu skali na odpowiedzi ankietowe. W: Antoni Sułek. Sondażpolski. Praygarść rozpraw o badaniach ankietowych. Warszawa: Wydawnictwo IFiS PAN/Instytut Socjologii UW, s. 175-187.

/// Sulek, Antoni. 2002. Od mobilizacji do nie-reprezentacji: PZPR w swietle statystyki własnej (1990). W: Antoni Sułek. Ogród metodologii socjologicznej. Warszawa: Wydawnictwo Naukowe Scholar, s. 148-162. 
/// Sułek, Antoni. 2011. Zwykli Polacy patrza na Żydów. Postawy spoteczeństwa polskiego wobec Żydow w swietle badań sondażonych (1967-2008). W: Feliks Tych, Maria Garbowska-Adamczyk (red.). Nastepstwa zagłady Żydów: Polska 1944-2010. Lublin: Wydawnictwo Uniwersytetu Marii Curie-Skłodowskiej, Żydowski Instytut Historyczny, s. 853-888.

/// Sułek, Antoni. W druku. „Wtadza Żydów” i stabnaca władza stereotypu. Eksperymentalne badanie wżduż сzasu. W: Kaja Kaźmierska, Renata Dopierała (red.), To:̇samość, stereotypy, nowoczesność. Kraków: Nomos.

/// TNS OBOP. 2008. Efekt „Strachu”, komunikat z badania.

/// TNS OBOP. 2010. O „wplywie Żydów” w Polsce, 2002-2010, komunikat z badania.

/// TNS OBOP. 2011. Struktura etniczna w spotecznej swiadomości, komunikat $\mathrm{z}$ badania.

/// Tokarska-Bakir, Joanna. 2011. How to exit the conspiracy of silence? Social sciences facing the Polish-Jewish relations. "East European Politics and Societies" 25, 1, s. 129-152.

/// Tourangeau, Roger, Rips, Lance J., Rasinski, Kenneth. 2000. The Psychology of Survey Response. Cambridge: Cambridge University Press.

/// Weil, Frederick D. 1985. The variable effects of education on liberal attitudes: A comparative-historical analysis of anti-Semitism using public opinion survey data. „American Sociological Review” 56, 4, s. 458-474.

/// Weil, Frederick D. 1987. The extent and structure of anti-Semitism in Western populations since the Holocaust. W: Helen Fein (ed.). The Persisting Question; Sociological Perspectives and Social Contexts of Modern Antisemitism. T. 1. Berlin: de Gruyter, s. 164-189.

/// Wilska-Duszyńska, Barbara. 1975. Postawy etniczne a niektóre elementy studenckiego systemu wartości. Warszawa: Instytut Polityki Naukowej i Szkolnictwa Wyższego.

/// Wisse, Ruth R. 1987. Poland's Jewish ghosts. „Commentary” 83, 1, s. 25-33.

/// Zaller, John R. 1992. The Nature and Origins of Mass Opinion. Cambridge: Cambridge University Press. 


\section{/// Abstrakt:}

Podręczniki metodologii badań sondażowych uczą pobierać reprezentacyjne próby, układać pytania, zadawać je respondentom oraz zliczać i analizować odpowiedzi. Nie ma natomiast podręczników interpretacji odpowiedzi, określenia znaczenia uzyskanych wyników, odnoszenia ich do pojęć, które konstruują doświadczenie. Można się tego uczyć, analizując przypadki badań i interpretacji. W pracy pokazano problemy określania znaczenia wyników badań ankietowych. Wykorzystano prowadzone w Polsce w latach 1967-2011 badania nad postawami wobec Żydów. Rozważono kolejno znaczenie występującego w kwestionariuszach sondażowych słowa „Żydzi”, problemy z określaniem znaczenia pytań i odpowiedzi numerycznych, pytań o postawy - sympatię i niechęć, bliskość i dystans, odpowiedzi wyrażających przekonania o władzy Żydów oraz problem znaczenia pytań i odpowiedzi w międzykrajowych badaniach porównawczych.

Słowa kluczowe:

badania sondażowe, znaczenie, postawy wobec Żydów, antysemityzm.

\section{/// Abstract:}

\section{On Method and Meaning in Survey Research. The Case of Rese- arching Attitudes Toward Jews}

Handbooks of survey research methodology tell how to draw representative samples, formulate questions, ask respondents, and how to count and analyse answers. However, there are no handbooks that teach how to interpret answers, determine meaning of results, and relate them to concepts that construct experience. One can only learn it by studying cases and exemplars. The article addresses problems of determining meaning of survey research results. It uses research on attitudes toward Jews conducted in Poland in years 1967-2011. The author deals with the meaning of the word "Jews" used in questionnaires, analyses problems with determining meaning of questions and numeric answers, looks into questions concerning attitudes - sympathy and aversion, proximity and distance, discusses answers showing convictions about power of Jews and answers in cross-country survey research.

Keywords:

survey research, meaning, attitudes toward Jews, antisemitism 